\title{
Roles of Fucosylation in Tumor Immunology
}

\author{
腫瘍免疫におけるフコシル化糖鎖の役割
}

\author{
Moriwaki, Kenta; and Miyoshi, Eiji \\ Department of Molecular Biochemistry and Clinical Investigation, Osaka University Graduate School of Medicine, \\ 1-7 Yamada-oka, Suita, Osaka 565-0871, Japan \\ FAX: 81- 6-6879-2590,E-mail: emiyoshi@sahs.med.osaka-u.ac.jp
}

(Received on June 10, 2010, accepted on August 18, 2010)

Key Words: fucosylation, tumor immune surveillance, natural killer cells, TRAIL

\begin{abstract}
The explosive progress of glycobiology in the past few decades has revealed that fucose is indispensable in various organisms and is involved in many biological events. Many researchers have spent a lot of time in order to unveil the mysterious functions of fucosylation. However, the findings which have ever been clarified are not sufficient to explain all fucosylation-related biological events. In the field of oncology, although several fucosylated molecules have been reported to be increased in cancer and have been used as cancer biomarkers, it remains unknown how dynamic changes of fucosylation are associated with cancer biology. Recently, we found that fucosylation is involved in NK cell-mediated tumor immune surveillance through regulation of the susceptibility to tumor necrosis factor-related apoptosis-inducing ligand (TRAIL), which is an apoptosis-inducing molecule. In this review, we describe the relationship between cancer biology and fucosylation, according to our recent findings.
\end{abstract}

\section{A. Introduction}

Glycosylation comprises the enzymatic attachment of sugars to biological macromolecules, such as proteins and lipids, and is one of the most important post-translational modifications. Fucose is a kind of monosaccharide that forms oligosaccharides through binding via glycosidic linkages. L-fucose is equivalent to 6-deoxy-L-galactose and exhibits two structural differences from other hexoses in mammals. One is the lack of a hydroxyl group on the carbon at the 6-position and the other is the L-configuration. Fucosylation is a reaction by which an L-fucose residue is attached to oligosaccharides on glycoproteins and glycolipids or proteins. Fucosylation can confer unique functional properties to oligosaccharides or proteins and is closely associated with various physiological events, including development, incompatible blood transfusion reaction, and leukocyte trafficking (1). In addition,
要 約

近年の糖鎖生物学の急速な発展に伴い、フコースが様々 な生物に扔いて必要不可欠なものであり、多くの生命現象に 関与することが明らかとなってきている。現在、多くの研究 者が分子レベルでフコシル化の機能を解明しょうと日夜努力 しているが、フコシル化が関与する生命現象を完全には解明 できていない。癌の分野においても、癌化に伴いフコシル化 が増加することが古くから知られて招り、いくつかのフコシ 儿化分子が腫瘍マーカーとして利用されてきたが、それが癌 の性質においてどのような生物学的意味を持っているのかに ついてはあまり理解されていない。最近、我々はフコシル化 がアポトーシス誘導分子である Tumor necrosis factor-related apoptosis-inducing ligand (TRAIL) による癌細胞のアポトーシ スを制御し、NK 細胞による腫瘍免疫監視機構に関与すること を明らかとした。本総説では、我々のこの新しい知見を中心に、 癌とフコシル化の関倸について概説したい

A. はじめに

グリコシル化とはタンパク質や脂質のような生体高分子 に糖を酵素的に付加する反応のことであり、生体において最 も重要な翻訳後修飾の一つである。糖鎖は単糖がグリコシド 結合を介して互いに結合することによって構成されているが、 その構成単糖の中にフコースと呼ばれるものがある。L-フコー スは 6- ゙゙オキシ -L- ガラクトースに相当するものであり、哺乳 類で見られるその他の六単糖とは 2 点の構造的相違点を持つ のが特徵である。一つ目は6位の炭素に水酸基が見られない点、 2つ目は異性体として D 体ではなく、L 体を使用する点である。 この L- フコースを糖タンパク質や糖脂質上の糖鎖や、また直 接タンパク質に付加する反応のことをフコシル化という。フ コシル化された糖鎖やタンパク質はそれぞれ特有の機能を発 揮するようになり、発生、不適合輸血反応、リンパ球の移動 など様々な生命現象と密接に関係している (1)。また、フコシ ル化は多くの種類の疾患、特に癌と深く関与していることが 
fucosylation is known to be deeply involved in many diseases, especially cancer and inflammation (2). In this review, we briefly outline the roles of fucosylation in cancer and immunology. Moreover, we would like to refer to our recent finding of a relationship between fucosylation and tumor immune surveillance.

\section{B. Regulatory Mechanism for Fucosylation}

Fucosylation is catalyzed by several fucosyltransferases, GDP-fucose, and GDP-fucose transporter(s) (Fig.1). Eleven functionally defined fucosyltransferases in the human genome have been reported. They are divided into four groups, namely $\alpha 1-2, \alpha 1-3 / 4$ and $\alpha 1-6$ fucosyltransferases, and protein $O$-fucosyltransferases. GDP-fucose is a kind of sugar nucleotide and serves as a common donor substrate for all fucosyltransferases. GDP-fucose is synthesized in the cytosol via two pathways: the salvage and de novo pathways. The salvage pathway catalyzed by L-fucokinase and GDP-fucose pyrophosphorylase is a very minor one. Almost all GDPfucose is synthesized through the de novo pathway, in which GDP-mannose is transformed into GDP-fucose via three steps: catalyzation by GDP-mannose 4,6-dehydratase (GMDS) $(3,4)$, and GDP-4-keto-6-deoxy-mannose-3,5-epimerase-4reductase (FX) (5). The synthesized GDP-fucose is transported
知られている (2)。本総説では、癌におけるフコシル化の役割 の概要を簡潔に述べ、我々が近年明らかにしたフコシル化と 免疫監視機構との関係について紹介したい。

\section{B. フコシル化の制御機構}

フコシル化はフコース転移酵素、GDP-フコース、GDPフコーストランスポーターといった分子によって担われて いる (図 1)。ヒトゲノム中では、今までに 11 種類のフコー 又転移酵素の機能が明らかとなっており、それらは $\alpha$ 1-2、 a 1-3/4、 a 1-6、O-フコース転移酵素といった 4 つのグルー プに分類することができる。これら全てのフコース転移酵素 の共通したドナー基質となるのが糖ヌクレオチドの一種であ るGDP-フコースである。この GDP-フコースは細胞質中でサ ルベージ経路と de novo 経路の 2 つの経路によって合成され る。サルベージ経路は L- フコキナーゼと GDP- フコースピロ フォスフォリラーゼによって担われている経路であるが、非 常にマイナーな経路である。細胞内 GDP-フコースのほとん ど全てはde novo 経路によって合成されている。この de novo 経路ではGDP-マンノースデヒドロゲナーゼ (GMDS)(3, 4) と GDP-4- ケト-6 デオキシマンノース -3, 5-エピメラーゼ-4- リ ダクターゼ $(\mathrm{FX})(5)$ によって担われている 3 段階の反応を経 て GDP-マンノースをGDP-フコースへと変換する。細胞質で 合成された GDP-フコースは、ゴルジ体膜上に存在している

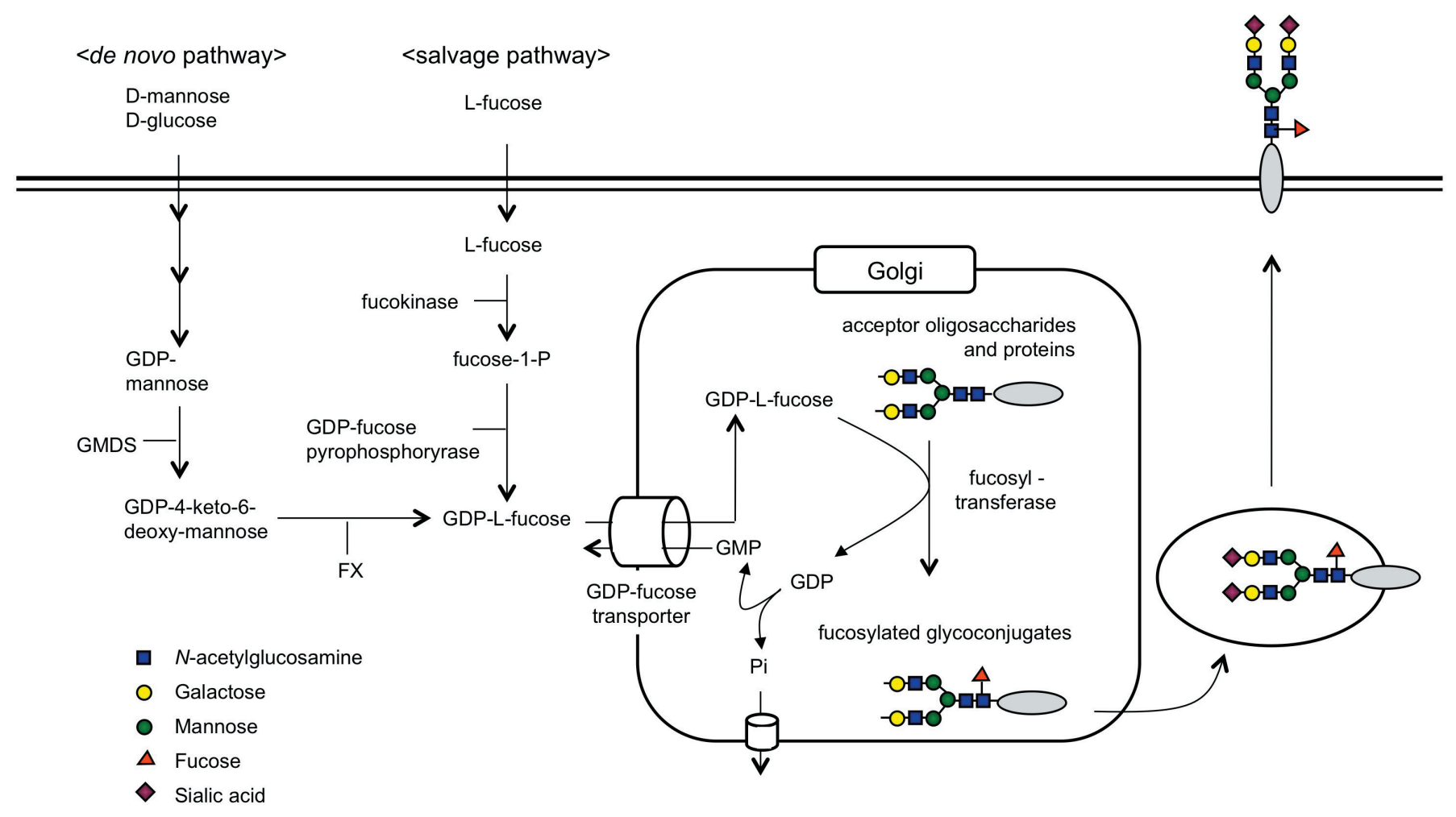

Fig. 1. Synthetic pathway for fucosylated oligosaccharides. GDP-fucose is synthesized in the cytosol via two pathways, namely the salvage and de novo pathways. Cytosolic GDP-fucose is transported into the Golgi apparatus through a Golgi-localized GDP-fucose transporter, and then is used as a donor substrate for fucosyltransferases. 
into the Golgi apparatus by a Golgi-localized GDP-fucose transporter to serve as a donor substrate for $\alpha 1-2, \alpha 1-3 / 4$, and $\alpha 1-6$ fucosyltransferases $(6,7)$. On the other hand, Protein $O$-fucosylation occurs in the endoplasmic reticulum (ER) in which $O$-fucosyltransferases, Pofut 1 and 2, are localized (8.9). Thus, cytosolic GDP-fucose also needs to be transported into the ER. Although the mechanism underlying the transport of cytosolic GDP-fucose into the ER lumen has been unclear for a long time, a dual system for supplying GDP-fucose to the ER was recently reported in Drosophila (10). In the first pathway, GDP-fucose is directly incorporated into the ER through the newly identified ER-localized GDP-fucose transporter. In the second pathway, GDP-fucose is incorporated into the Golgi apparatus through the Golgi-localized GDP-fucose transporter and then transported into the ER, possibly via retrograde vesicular trafficking from the Golgi to the ER. The change in fucosylation can't be explained by the expression of a single molecule among these fucosylation-related ones (11-13). We need to comprehensively analyze the synthesis, transport, and transfer of GDP-fucose in order to understand the dynamic regulation of fucosylation in various biological events.

\section{Cancer and Fucosylation}

Fucosylated oligosaccharides and proteins have been used as cancer biomarkers since they were found a few decades ago to be increased in the serum of patients with cancer. Fucosylated alpha-fetoprotein (AFP), which is named the AFP-L3 fraction after the measurement method used, has been clinically used as a specific cancer biomarker for hepatocellular carcinoma (HCC) since 1996 in Japan and 2005 in the United States $(14,15)$. In addition, advanced large-scale analytical methods involving a fucose-recognizing lectin for human serum glycoproteome recently revealed glycoprotein 73 (GP73) is a novel cancer biomarker for HCC (16). The amount and fucosylation of GP73 are increased in serum from patients with HCC. GP73 and fucosylated GP73 are expected to become useful cancer biomarkers with high sensitivity and specificity. In the case of pancreatic cancer, a fucosylated oligosaccharide, sialyl Le ${ }^{a}$ [NeuAco2-3Gal $\beta 1-3$ (Fuc $\alpha 1$ 4)GlcNAc $\beta 1-R]$, namely CA19-9, has been used as a specific cancer biomarker (17). Recently, we reported the potential use of fucosylated haptoglobin, the positive rate for which is $60-70 \%$ in pancreatic cancer, which increases progressively with the stage of the disease, as a novel cancer biomarker (18-20). Now, we are performing a validation study using sera from many patients with cancer in order to estimate the clinical availability of an ELISA kit for the measurement of fucosylated haptoglobin. In addition to application of fucosylation as cancer biomarkers, several studies have demonstrated its biological function in cancer. Fucosylated tetrasaccharide structures, sLe ${ }^{x}$ [NeuAc $\alpha 2-3$ Gal $\beta 1-4$ (Fuc $\alpha 1-$
GDP- フコーストランスポーターによってゴルジ体内腔に輸送 され、 $a$ 1-2、 $a$ 1-3/4、 a 1-6フコース転移酵素のドナー基 質として利用される $(6,7)$ 。一方、 $O$ - フコース転移酵素である Pofut1 と Pofut2 は小胞体に局在しており、O-フコシル化は小 胞体内腔で起こる $(8,9)$ 。そのため、細胞質 GDP-フコースは 小胞体内腔へも輸送される必要がある。長らく、細胞質 GDPフコースがどのようにして小胞体内腔へ輸送されるのか明ら かとなっていなかったが、最近、小胞体へGDP-フコースを輸 送する 2 つシステムの存在がショウジョウバエで報告され た (10)。一つ目は、新しく同定された小胞体局在型 GDP-フコー ストランスポーターを介して細胞質 GDP-フコースを直接小胞 体内腔へ輸送するというシステムであり、2つ目はゴルジ体局 在型 GDP-フコーストランスポーターによってゴルジ体内腔へ 輸送された GDP-フコースが逆行膜輸送によってゴルジ体から 小胞体へ輸送されるというシステムである。このようにフコ シル化の制御には多くの分子が関与しており、フコシル化の 変化をどれか一つの分子で説明することはできず、様々な場 面でフコシル化がどのように制御されているのかを理解する ためには GDP-フコースの合成・輸送・転移とを包括的に解析 する必要がある (11-13)。

\section{C. 癌とフコシル化}

数十年前に、癌患者血清中でフコシル化糖鎖、もしくは ある種のフコシル化糖タンパク質が増加するということが発 見されて以来、これらは腫瘍マーカーとして利用されてき た。フコシル化された $\alpha$ フェトプロテイン $(\mathrm{AFP})($ その測定法 にちなんで AFP-L3 分画と呼ばれる) は肝細胞癌に特異的な 腫瘍マーカーとして日本では 1996 年から、米国でも 2005 年 から臨床的に利用されている $(14,15)$ 。近年、フコースを認識 するレクチンを用いた高度な大規模ヒト血清グライコプロテ オーム解析を通して、グライコプロテイン 73(GP73) が肝細胞 癌の新規腫瘍マーカーとして同定された (16)。GP73の発現レ ベルとそのフコシル化レベルは肝癌患者血清中で増加してお り、感度・特異度ともに優れた腫瘍マーカーとなることが期 待されている。脺癌でも、フコシル化糖鎖であるシアリルル イス A [NeuAc a 2-3Gal $\beta$ 1-3(Fuc a 1-4)GlcNAc $\beta$ 1-R]、す なわち CA19-9、が膵癌特異的腫瘍マーカーとして利用されて きた (17)。最近、我々はフコシル化ハプトグロビンが新たな 膵癌の腫瘍マーカーとなることを報告した。このフコシル化 ハプトグロビンの膵癌における陽性率は $60 \sim 70 \%$ であり、癌 の進行とともに増加していく (18-20)。現在は、フコシル化ハ プトグロビン測定のための ELISA キットの臨床的有用性を 多くの血清サンプルを用いて評価している。このように、フ コシル化は腫瘍マーカーとして応用され、その有用性が確立 されてきたが、フコシル化の癌における生物学的機能につい てもいくつかの報告がなされてきた。フコースを含む 4 糖 構造であるシアリルルイス X [NeuAc a 2-3Gal $\beta$ 1-4(Fuc a 13)GlcNAc $\beta$ 1-R] やシアリルルイス A はセレクチンのリガンド として機能することが知られている。セレクチンは、C 型レク 
3)GlcNAc $\beta 1-R$ ] and sLe ${ }^{a}$, are known to be recognized by selectins, which perhaps comprise the best-characterized family of C-type lectins and are expressed on the surface of endothelial cells, leukocytes, and platelets (21). The binding of $\mathrm{sLe}^{\mathrm{x}}$ or $\mathrm{sLe}^{\mathrm{a}}$ on cancer cells to E-selectin on endothelial cells facilitates tumor metastasis (22). In fact, the expression of these determinants in epithelial cancer has been reported to correlate with the poor prognosis of human colon cancer (23). In addition, $\alpha 1-6$ fucosylation (core fucosylation) is crucial for the functions of several growth factor receptors, such as EGF (24) and TGF- $\beta$ receptors (25), and adhesion molecules, such as integrins (26) and E-cadherin (27). Core fucosylation is very closely involved in the biological behavior of cancer cells through regulation of the functions of these membraneassociated receptors (28). Thus, fucosylation is a modulator closely involved in the characteristics of cancer cells rather than a marker representing the consequence of carcinogenesis.

\section{The Role of Fucosylation in Tumor Immunity}

It is a well-known fact that glycosylation plays an important role in the immune system partly through glycanlectin binding (29). Lectins are proteins that recognize and bind to specific oligosaccharide structures. Many kinds of lectins, such as C-type lectins including the selectin family, the I-type lectin including Siglec family, and the galectin family regulate various steps during immune reactions. The immune system can specifically identify and eliminate tumor cells on the basis of their expression of tumor-specific antigens or molecules induced by cellular stress. This system for primary defense against cancer cells is referred to as tumor immune surveillance. Regarding the function of fucosylated oligosaccharides in tumor immunity, it was recently reported that glycosylation-dependent interactions between colorectal carcinoma-associated Le glycans and Dendritic Cell Specific Intercellular adhesion molecule-3 Grabbing Non-integrin (DCSIGN), a kind of lectin expressed on dendritic cells, resulted in down-regulation of the immunological function of dendritic cells followed by attenuation of tumor immunity (30).

Natural killer (NK) cells are a type of cytotoxic lymphocyte and are one of the key players in tumor immune surveillance. NK cells sense and kill cells with abnormalities such as "missing-self" or "altered-self" through a large repertoire of inhibitory and activating receptors (31). NK inhibitory receptors recognize MHC class I molecules ubiquitously expressed on almost all normal cells and suppress the activation of NK cells. Thus, NK inhibitory receptors prevent inappropriate NK cell activation followed by destruction of normal cells in the body and are responsible for self-tolerance. Abnormal cells that lose MHC class I molecules are killed by NK cells, which is referred to as the "missing self theory". Despite this, NK cells can also become
チンの一種であり、血管内皮細胞、リンパ球、血小板などの 細胞表面上に発現している (21)。癌細胞表面上に発現してい るシアリルルイス X やシアリルルイス $\mathrm{A}$ が血管内皮細胞表面 上に発現しているE-セレクチンに結合することによって、癌 の転移が促進されることとなる $(22)$ 。実際、上皮癌に扔ける シアリルルイス $\mathrm{X}$ やシアリルルイス $\mathrm{A}$ の発現量が、癌患者の 予後と相関することが報告されている (23)。その他には、コ アフコシル化と呼ばれる $a$ 1-6 結合のフコシル化が、上皮増殖 因子 (EGF)(24) や腫瘍増殖因子 (TGF- $\beta$ )(25) などの増殖因子、 また、インテグリン (26)やE-カドヘリン (27)などの接着分子 が機能する上で、非常に重要な働きをしていることが分かっ てきている。そのため、コアフコシル化はこれらの分子を含 む膜結合型タンパク質の機能を制御することによって癌細胞 の性質に深く関係していると考えられる(28)。このようにフコ シル化は癌化の結果を表わす単なる指標というよりもむしろ、 癌の性質に密接に関係しているモジュレーターであると言える。

\section{D. 腫瘍免疫と糖鎖}

グリコシル化は生体内の免疫システムにおいて非常に重 要な役割を果たすことがよく知られており、その機能は糖鎖 とレクチンとの結合によって発揮されることが多い (29)。レ クチンとは特定の糖鎖構造を認識し、結合するタンパク質で あり、セレクチンなどに代表されるC 型レクチン、シグレッ クなどに代表されるI型レクチン、そしてガレクチンなど多 くのレクチンは様々な免疫反応を制御している。生体内の免 疫システムは、癌細胞に発現する癌特異的抗原や、ストレス 誘導性分子などを察知して、その癌細胞を特異的に体内から 排除している。このシステムは癌細胞に対する第一の防御と して機能し、腫瘍免疫監視機構と呼ばれる。この腫瘍免疫に おけるフコシル化糖鎖の機能に関して、大腸癌細胞表面上に 発現するルイス型糖鎖が樹状細胞に発現するレクチンである DC-SIGN に結合し、樹状細胞の持つ免疫機能を抑制し、腫瘍 免疫を減弱させることが近年報告されている (30)。

ナチュラルキラー (NK) 細胞は細胞障害性リンパ球の一種 であり、腫瘍免疫監視機構に扔ける中心的な免疫細胞として 働く。NK 細胞は非常に多くの種類の活性化受容体、抑制性受 容体を自身の細胞表面上に発現して扔り、それらを介して「自 己を衰失した細胞」「自己が変化した細胞」を異常な細胞とし て感知し、殺傷する (31)。NK 細胞の活性化は、NK 抑制性受 容体が MHC クラス I 分子を認識すると、抑制されることと なる。この MHC クラス I 分子はほとんど全ての正常細胞で発 現しているため、NK 抑制性受容体は不適切な NK 細胞の活 性化による生体内の正常細胞の破壞を防ぎ、自己宽容を担っ ている。MHCクラスI分子の発現を失い、「自己を峦失した」 異常な細胞は NK 細胞によって殺傷され、このような機構は $\lceil$ missing self 理論」と呼ばれる。しかし、このような機構が ある一方、標的細胞表面上に NK 活性化受容体のリガンドが 
stimulated when target cells express sufficient specific ligands for NK activation receptors to dominate over inhibitory signals. It is now common knowledge that the activation of NK cells depends on an intricate balance between activating and inhibitory signals. Structurally, these NK receptors mostly belong to either the immunoglobulin superfamily or the C-type lectin superfamily. Both groups of NK receptors comprise activating and inhibitory receptors. Thus, oligosaccharide modifications have been suggested to be involved in the recognition of target cells by NK cells since the discovery of C-type lectins like NK receptors. In fact, it has been reported that sialyl $\mathrm{Le}^{\mathrm{x}}$ regulates the activity of NK cells through binding to CD94 $(32,33)$. Although several other studies have also suggested the importance of glycans as ligands for C-type lectins-like NK receptors, further studies need to be performed to reveal the involvement and significance of glycans in the recognition of target cells by NK cells.

\section{E. GMDS Mutation Leads to Escape from NK Cell- Mediated Tumor Immune Surveillance in Colon Cancer}

When we investigated the fucosylation levels in several cancer cell lines, we found a fucosylation-deficient colon cancer cell line, HCT116. RT-PCR and sequencing analysis involving RNA from HCT116 cells revealed that the cells had a GMDS transcript with deletion of exons 5, 6, and 7 (Fig. 2A). Transfection of wild-type GMDS restored the cellular fucosylation in HCT116 cells (Fig. 2B), indicating that the
抑制性シグナルを凌駕する程に発現していると、NK 細胞は活 性化されることとなる。そのため、抑制性シグナルと活性化 シグナルの間の複雑なバランスが NK 細胞の活性化を規定し ているというのが現在の共通した見解であろう。今までに数 多くの NK 受容体が同定されてきたが、そのほとんどが、免 疫グロブリンスーパーファミリーもしくはC 型レクチンスー パーファミリーのどちらかに属している。C型レクチン様の $\mathrm{NK}$ 受容体が発見されて以来、NK 細胞による標的細胞の認識 に糖鎖が関与することが示唆されてきた。実際、癌細胞表面 上のシアリルルイス X が NK 受容体である CD94 との結合を 介して NK 細胞の活性化を制御するということが報告されて いる $(32,33) 。 そ の$ 他にも C 型レクチン様 NK 受容体のリガン ドとしての糖鎖の重要性を示唆する研究が報告されているが、 $\mathrm{NK}$ 細胞による標的細胞の認識における糖鎖の関与と意義を明 かにするにはまだまだ多くの解析が必要であると思われる。

\section{E. 大腸癌は GMDS の遺伝子変異によりNK 細胞を介した腫瘍} 免疫を回避する

我々は以前に数種類の癌細胞株におけるフコシル化レベ ルを調べていた際に、HCT116という大腸癌細胞株ではフコ シル化が欠損していることを見出した(図 2A)。この HCT116 細胞では GDP - フコース合成酵素 GMDS の転写産物のエクソ ン 5, 6, 7 が久損しており、野生型 GMDS を同細胞に導入する とフコシル化が回復したことから (図 2B)、HCT116 細胞では GMDSの遺伝子変異によりフコシル化が欠損していることが

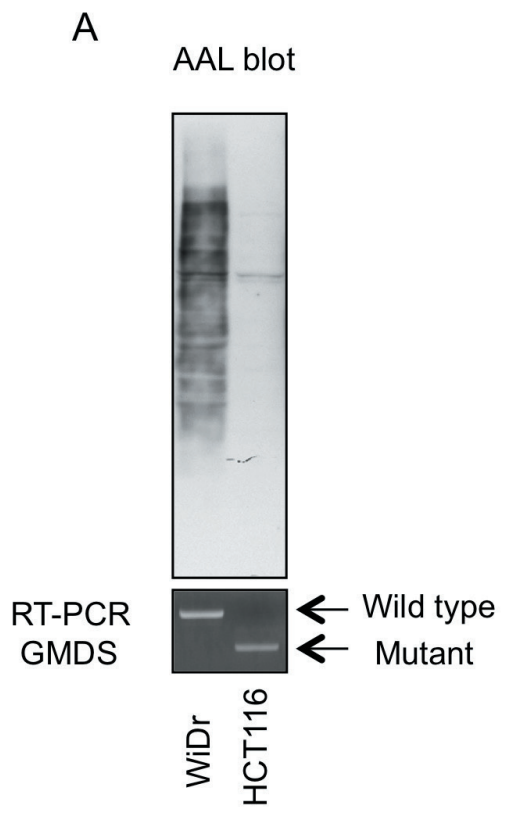

B

AAL blot

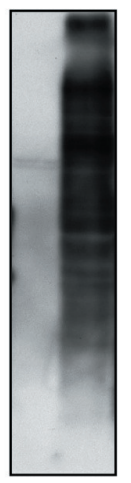

들
C

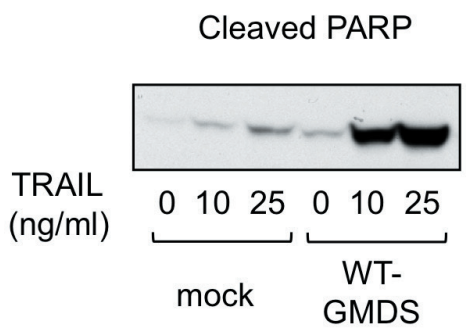

Fig. 2. HCT116 cells show loss of fucosylation because of GMDS mutation, resulting in escape from NK cell-mediated tumor immune surveillance through the acquisition of resistance to TRAIL. A. AAL lectin blot and RT-PCR analyses were performed using proteins and RNAs derived from WiDr, and HCT116 cells, respectively. B. After transfection of the wild-type GMDS gene into HCT116 cells, restoration of fucosylation was examined by AAL lectin blot analysis. C. After treatment of mock and GMDS-rescued cells with recombinant TRAIL, the expression level of cleaved PARP, which is an indicator of apoptosis, was examined by Western blot analysis. 
deficiency of fucosylation in HCT116 cells was caused by a mutation of the GMDS gene. As shown in Fig. 2B, fucosylation-deficient (mock) cells and fucosylation-restored (GMDS-rescued) cells are good tools for examining the roles of fucosylation in the behavior of cancer cells. At first, no difference of in vitro cell growth between mock and GMDSrescued cells was observed. However, when both types of cells were inoculated into the backs of athymic nude mice, in vivo tumor growth of the GMDS-rescued cells was surprisingly decreased compared with that of the mock cells. These results allowed us to hypothesize that the host's immune responses were involved in the decreased tumor growth of the GMDSrescued cells. Because athymic nude mice have a deficiency of T cells, NK cells mainly play an important role in tumor immune surveillance. When we depleted NK cells by injecting asialo GM1 antibody into athymic nude mice, tumor growth of the GMDS-rescued cells was significantly increased (Fig. 3E in reference 34). NK cells recognize target cells by activating and inhibitory receptors, and then induce apoptosis of the cells through the perforin/granzyme pathway and death ligand/death receptor-mediated pathway. It has been reported that tumor necrosis factor-related apotosis-inducing ligand (TRAIL), which is a death ligand family member, especially plays a very important role in NK cell-mediated tumor immune surveillance. TRAIL induces apoptosis to cancer cells through the engagement to cognate TRAIL receptors. Our further analyses revealed that the GMDS-rescued cells were significantly more susceptible to TRAIL-induced apoptosis (Fig. 2C), which caused increased sensitivity of the GMDSrescued cells to NK cells $(34,35)$. Although the details of the mechanism by which fucosylation regulates TRAIL-induced apoptosis have not yet been elucidated, these phenomena are very important as new functions of fucosylation in tumor immunity. Aberrant transcripts of GMDS were found in other cancer cell lines as well as several human cancer tissues, suggesting that loss of GMDS might be a common mechanism for cancer cells to evade NK cell-mediated tumor immune surveillance.

\section{F. Closing Remarks}

Our finding that fucosylation controls the sensitivity to NK cells through regulating death ligand-induced apoptosis will open up a new research field in "glcosylation and tumor immunity". Because the TRAIL/TRAIL receptor pathway also plays an important role in tumor immune surveillance mediated by other lymphocytes as well as NK cells (36), our findings might have more biological significance. However, it is indispensable to reveal the mechanism in detail to further develop this research. How does fucosylation regulate TRAIL signaling? When does loss of fucosylation occur during carcinogenesis and tumor progression? What is the biological
明らかとなった。図 2B で示したフコシル化欠損 mock 細胞と フコシル化回復 GMDS 導入細胞の両細胞は癌細胞に扔けるフ コシル化の役割を検討するのに非常にいいッールとなると思 われたので、両細胞の in vitroに打ける細胞増殖について調べ てみたが特に変化は見られなかった。ところが、両細胞をヌー ドマウスの背部に皮下移植したところ、驚いたことにGMDS 導入細胞は mock 細胞に比心゙、非常に小さな腫瘍しか形成せ ず、in Vivoでの腫瘍増殖が著しく抑制されていた。これらの in vitro と in vivo の結果から、我々は GMDS 遺伝子導入によ る腫瘍形成能の抑制に宿主側となるマウスの免疫系が関与し ているのではないかという仮説を立てた。胸腺が欠損してい るヌードマウスでは T 細胞が久損しているため NK 細胞が免 疫監視機構に扔いて主要な免疫細胞となる。そこで、アシア 口 GM1 抗体を用いて NK 細胞を除去してみると、GMDS 導 入細胞も非常に大きな腫瘍を形成するようになった ( 文献 34、 図 $3 \mathrm{E})$ 。 NK 細胞は標的細胞を認識した後、パーフォリン/グ ランザイムを介した系、そしてデスリガンド/デス受容体を 介した系を用いて、標的細胞にアポトーシスを誘導する。特 に、デスリガンドファミリーに属する Tumor necrosis factorrelated apoptosis-inducing ligand (TRAIL)が NK 細胞による 腫瘍免疫監視機構において重要な役割を果たしていることが 近年報告されてきている。TRAIL は対応する受容体を介して 癌細胞にアポトーシスを誘導する活性を有しているため、我々 は野生型 GMDS 導入細胞の TRAILへの感受性について調べ てみた。すると、GMDS 導入細胞では mock 細胞に比べ著し いTRAIL 誘導性アポトーシスが確認され(図 2 C)、詳細な解 析の結果、これが GMDS 導入細胞の NK 細胞に対する感受性 の増加の原因であることが明かとなった $(34,35)$ 。フコシル化 がどのようにして TRAIL 誘導性アポトーシスを制御してい るかについての詳細なメカニズムは明かとはなっていないが、 この現象は腫瘍免疫におけるフコシル化の新たな機能として 非常に重要なものである。GMDS 遺伝子の変異は HCT116 細 胞以外のヒト癌細胞株、並びにヒト臨床癌組織でも見出され ており、GMDSの欠損は癌細胞が腫瘍免疫監視機構を回避す るための共通したメカニズムであるのかもしれない。

\section{F. 終わりに}

フコシル化がデスリガンド誘導性のアポトーシスを制御 することによってNK 細胞への感受性を調節しているという 発見は、糖鎖と腫瘍免疫という枠組みの中で新たな研究分野 を開拓するものであると考えられる。TRAIL/TRAIL 受容体 の系は、NK 細胞だけでなくその他のリンパ球による腫瘍免疫 監視機構でも重要な役割を果たしていることが明らかとなっ ているため (36)、更なる研究の発展が期待されるが、それには 詳細なメカニズムの解明が必要不可欠であろう。フコシル化 がどのようにして TRAIL シグナリングの活性化を制御してい るのか、脱フコシル化は癌化の過程のどの段階で起こり、癌 にとってどのような意味を持つのかなど、細胞レベル/臨床 
role of loss of fucosylation? Further analysis should be performed using cultured cell lines and human cancer tissues. Although we need to solve many problems and might spend lots of time to completely elucidate the mechanisms, we expect that further analyses would open up the exciting world of fucosylation-mediated tumor immunity.

\section{G. Acknowledgements}

We thank Professor Naoyuki Taniguchi (the Institute of Scientific and Industrial Research, Osaka University), Dr. Katsuhisa Noda, Professor Norio Hayashi (Department of Gastroenterology and Hepatology, Osaka University Graduate School of Medicine), and Professor Yoichi Furukawa (Institute of Medical Science, The University of Tokyo) for great teaching and cooperation.
組織レベルでの更なる解析が必要である。フコシル化と腫瘍 免疫の関係にはまだまだ多くの課題が残されており、その理 解には長い時間がかかるかもしれないが、今後の更なる解析 によってワクワクするような世界が見えてくるのではないか と期待している。

\section{G. 謝 辞}

本研究の遂行に当たり、大阪大学産業科学研究所の谷口直 之教授、大阪大学医学部消化器内科の野田勝久先生、林紀夫 先生、東京大学医科学研究所の古川洋一先生に多大なご指導、 ご協力をいただきました。ここに深く感謝いたします。

\section{References}

1. Becker, D. J., and Lowe, J. B. (2003) Glycobiology 13, 41R-53R.

2. Moriwaki, K., and Miyoshi, E. (2010) World Journal of Hepatology (in press).

3. Sullivan, F. X., Kumar, R., Kriz, R., Stahl, M., Xu, G. Y., Rouse, J., Chang, X. J., Boodhoo, A., Potvin, B., and Cumming, D. A. (1998) J. Biol. Chem. 273, 8193-8202.

4. Ohyama, C., Smith, P. L., Angata, K., Fukuda, M. N., Lowe, J. B., and Fukuda, M. (1998) J. Biol. Chem. $273,14582-14587$.

5. Tonetti, M., Sturla, L., Bisso, A., Benatti, U., and De Flora, A. (1996) J. Biol. Chem. 271, 27274-27279.

6. Luhn, K., Wild, M. K., Eckhardt, M., Gerardy-Schahn, R., and Vestweber, D. (2001) Nat. Genet. 28, 69-72.

7. Lubke, T., Marquardt, T., Etzioni, A., Hartmann, E., von Figura, K., and Korner, C. (2001) Nat. Genet. $28,73-76$.

8. Harris, R. J., and Spellman, M. W. (1993) Glycobiology 3, 219-224.

9. Luo, Y., Nita-Lazar, A., and Haltiwanger, R. S. (2006) J. Biol. Chem. 281, 9385-9392.

10. Ishikawa, H. O., Ayukawa, T., Nakayama, M., Higashi, S., Kamiyama, S., Nishihara, S., Aoki, K., Ishida, N., Sanai, Y., and Matsuno, K. (2010) J. Biol. Chem. 285, 4122-4129.

11. Miyoshi, E., Moriwaki, K., and Nakagawa, T. (2008) J. Biochem. 143, 725-729.

12. Noda, K., Miyoshi, E., Gu, J., Gao, C. X., Nakahara, S., Kitada, T., Honke, K., Suzuki, K., Yoshihara, H., Yoshikawa, K., Kawano, K., Tonetti, M., Kasahara, A., Hori, M., Hayashi, N., and Taniguchi, N. (2003) Cancer Res. 63, 6282-6289.

13. Moriwaki, K., Noda, K., Nakagawa, T., Asahi, M., Yoshihara, H., Taniguchi, N., Hayashi, N., and Miyoshi, E. (2007) Glycobiology 17, 1311-1320.

14. Aoyagi, Y., Isemura, M., Suzuki, Y., Sekine, C., Soga, K., Ozaki, T., and Ichida, F. (1985) Lancet 2, 1353-1354.

15. Food and Drug Administration, HHS. (2005) Fed. Regist. 70, 57748-57750.

16. Block, T. M., Comunale, M. A., Lowman, M., Steel, L. F., Romano, P. R., Fimmel, C., Tennant, B. C., London, W. T., Evans, A. A., Blumberg, B. S., Dwek, R. A., Mattu, T. S., and Mehta, A. S. (2005) Proc. Natl. Acad. Sci. USA 102, 779-784.

17. Szymendera, J. J. (1986) Tumour Biol. 7, 333-342.

18. Okuyama, N., Ide, Y., Nakano, M., Nakagawa, T., Yamanaka, K., Moriwaki, K., Murata, K., Ohigashi, H., Yokoyama, S., Eguchi, H., Ishikawa, O., Ito, T., Kato, M., Kasahara, A., Kawano, S., Gu, J., Taniguchi, N., and Miyoshi, E. (2006) Int. J. Cancer 118, $2803-2808$.

19. Narisada, M., Kawamoto, S., Kuwamoto, K., Moriwaki, K., Nakagawa, T., Matsumoto, H., Asahi, M., Koyama, N., and Miyoshi, E. (2008) Biochem. Biophys. Res. Commun. 377, 792-796.

20. Matsumoto, H., Shinzaki, S., Narisada, M., Kawamoto, S., Kuwamoto, K., Moriwaki, K., Kanke, F., Satomura, S., Kumada, T., and Miyoshi, E. (2010) Clin. Chem. Lab. Med. 48, 505-512.

21. Barthel, S. R., Gavino, J. D., Descheny, L., and Dimitroff, C. J. (2007) Expert Opin. Ther. Targets 11, $1473-1491$.

22. Konstantopoulos, K., and Thomas, S. N. (2009) Annu. Rev. Biomed. Eng. 11, 177-202.

23. Nakamori, S., Kameyama, M., Imaoka, S., Furukawa, H., Ishikawa, O., Sasaki, Y., Kabuto, T., Iwanaga, T., Matsushita, Y., and Irimura, T. (1993) Cancer Res. 53, 3632-3637.

24. Wang, X., Gu, J., Ihara, H., Miyoshi, E., Honke, K., and Taniguchi, N. (2006) J. Biol. Chem. 281, 2572-2577.

25. Wang, X., Inoue, S., Gu, J., Miyoshi, E., Noda, K., Li, W., Mizuno-Horikawa, Y., Nakano, M., Asahi, M., Takahashi, M., Uozumi, N., Ihara, S., Lee, S. H., Ikeda, Y., Yamaguchi, Y., Aze, Y., Tomiyama, Y., Fujii, J., Suzuki, K., Kondo, A., Shapiro, S. D., Lopez-Otin, C., Kuwaki, T., Okabe, M., Honke, K., and Taniguchi, N. (2005) Proc. Natl. Acad. Sci. USA 102, 15791-15796.

26. Zhao, Y., Itoh, S., Wang, X., Isaji, T., Miyoshi, E., Kariya, Y., Miyazaki, K., Kawasaki, N., Taniguchi, N., and Gu, J. (2006) J. Biol. Chem. 281, 38343-38350.

27. Osumi, D., Takahashi, M., Miyoshi, E., Yokoe, S., Lee, S. H., Noda, K., Nakamori, S., Gu, J., Ikeda, Y., Kuroki, Y., Sengoku, K., Ishikawa, M., and Taniguchi, N. (2009) Cancer Sci. 100, 888-895.

28. Takahashi, M., Kuroki, Y., Ohtsubo, K., and Taniguchi, N. (2009) Carbohydr. Res. 344, 1387-1390.

29. Marth, J. D., and Grewal, P. K. (2008) Nat. Rev. Immunol. 8, 874-887.

30. Nonaka, M., Ma, B. Y., Murai, R., Nakamura, N., Baba, M., Kawasaki, N., Hodohara, K., Asano, S., and Kawasaki, T. (2008) J. Immunol. 180, 3347-3356. 
31. Biassoni, R. (2009) Curr. Protoc. Immunol. Chapter 14, Unit 1410.

32. Ohyama, C., Tsuboi, S., and Fukuda, M. (1999) EMBO J. 18, 1516-1525.

33. Ohyama, C., Kanto, S., Kato, K., Nakano, O., Arai, Y., Kato, T., Chen, S., Fukuda, M. N., and Fukuda, M. (2002) Proc. Natl. Acad. Sci. U SA 99, 13789-13794.

34. Moriwaki, K., Noda, K., Furukawa, Y., Ohshima, K., Uchiyama, A., Nakagawa, T., Taniguchi, N., Daigo, Y., Nakamura, Y., Hayashi, N., and Miyoshi, E. (2009) Gastroenterology 137, 188-198, 198 e181-182.

35. Haltiwanger, R. S. (2009) Gastroenterology 137, 36-39.

36. Johnstone, R. W., Frew, A. J., and Smyth, M. J. (2008) Nat. Rev. Cancer 8, 782-798.

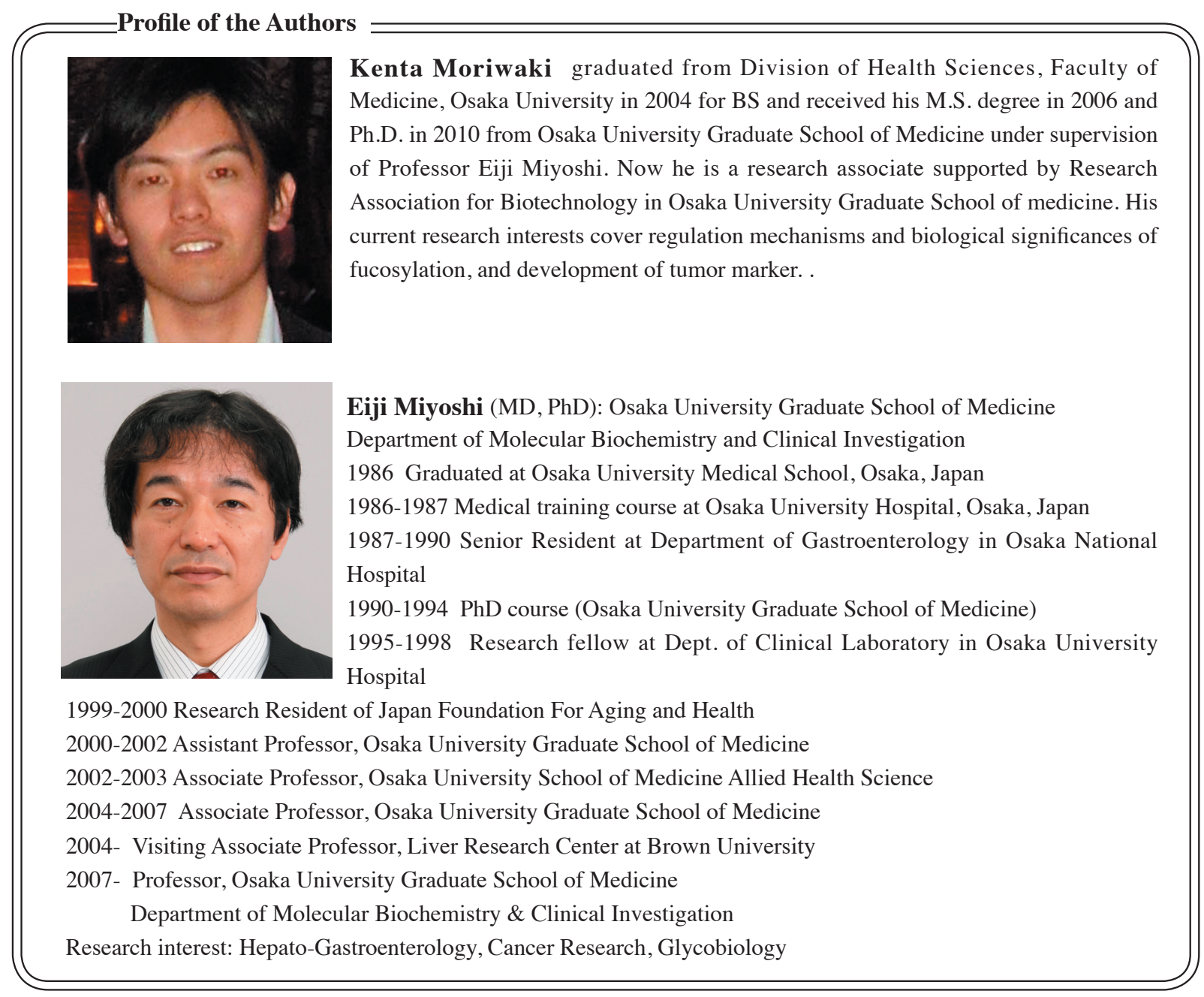

